\title{
Study of Serum Leptin in Polytransfused Children with Beta Thalassemia Major
}

\author{
Ahmed Mohamed Abd EL-Gawad Asfour*, Ali Abd El-Latif Afia*, Mohamed Saeed El- \\ Shorbgy** and Mohamed Abd El-kareim Mohamed* \\ Pediatric Department* and Clinical pathology Department**, Faculty of Medicine Al-Azhar \\ University
}

Corresponding author: Ahmed Mohamed Abd EL-Gawad Asfour, email: drahmedasfour14@gmail.com

\begin{abstract}
Background: thalassemic patients with frequent blood transfusion can result in iron overload and increase serum ferritine level. Leptin is a polypeptide hormone that is mainly expressed in bone marrow and adipocytes and previous studies consumed that it is lower in thalassemic patients compared to healthy children as a result of hemsedrosis.

Objectives: The aim of this study was to evaluate leptin serum levels in patients with $\beta$ - thalassemia major.

Patients and methods: This case-control study was conducted on 50 children from 13 to 17 years old, at Al-Azhar university Hospitals (Sayed Galal \& Al-Hussien hospitals). They were subdivided in two groups 30 patients ( $B$-thalassemia major) and 20 as control that were matched in age and sex. All Children were examined to be free from heart disease, iron deficiency anemia, kidney disease, diabetes, fever and systemic diseases were enrolled after taking informed consent of their parents. After collecting the samples, leptin and ferritin levels of the serum were measured in two groups by ELISA method .Then, the data were analyzed by the related statistical tests and SPSS 20 software.

Results: The mean of the serum levels of leptin and ferritin showed a significant difference in the case and control groups $(\mathrm{P}$-value $<0.05)$. Levels of leptin in the case group showed no significant gender difference $(\mathrm{P}-\mathrm{value}<0.05)$.

Conclusion: Based on the results of this study, thalassemia major reduces serum levels of leptin regardless of age and body mass .
\end{abstract}

Keywords: Beta-Thalassemia; Child, Ferritin, Leptin.

\section{INTRODUCTION}

Every year 100,000 neonates are born with hemoglobinopathies around the world. Thalassemia is the most common heterogeneous disease of the human being. Recently, the quantity and quality of the life of these patients have been significantly improved by regular transfusion and iron chelating therapy ${ }^{(1)}$.

Leptin, a polypeptide of 146 amino acids, is an obesity gene product, which is widely produced in different tissues, including bone marrow and adipocyte ( also known as lipocytes and fat cells, are the cells that primarily compose adipose tissue, specialized in storing energy as fat) and has a direct correlation with body mass index ${ }^{(2)}$. This hormone is multifunctional that leads to increase energy levels, and affects angiogenesis, inflammation, and hematopoiesis. It is regulated by an intricate complex, which includes glucocorticoids, thyroid and insulin ${ }^{(3)}$.

Bone marrow contains active obesity genes as well as fat cells. The fat content of bone marrow in human regulates his/ her hematopoiesis activity ${ }^{(4)}$. The structural similarity between the leptin receptor and the cytokines signaling molecules of the hematopoiesis system improves the growth potential of the active hormones in form of blood cells ${ }^{(5)}$. In addition, leptin binds to the hematopoietic complementary DNA receptor of humans and the destruction of leptin receptor stimulates the defected production of erythrocyte products ${ }^{(4)}$. Consequently, due to mutations in the major beta-thalassemia, several breaks occur in process of red blood cells maturation and antagonized with some complications such as osteoporosis, hepatosplenomegaly, hypothyroidism and 
insulin resistance ${ }^{(6)}$. Based on the important role of vascular chronic inflammation in the pathophysiology of complications in thalassemia, the most crucial factors for creating this implication are hemolysis, impaired erythropoiesis and inflammation ${ }^{(7)}$.

Ferritin reflects the iron storage of body with the normal value of 150 to $300 \mu \mathrm{g} / \mathrm{l}$. Here, because of iron overload, we face an increase of ferritin level in thalassemia patients ${ }^{(8)}$. Studies on relationship between ferritin and leptin suggested a possible link, which is independent of its relationship with BMI and inflammation. These studies suggested that iron overload might lead to a decrease in leptin level.

Chronic hemolysis can also increase platelet and erythrocyte adhesions to endothelial cells. And therefore, increases in iron amounts have an important role in damage and inflammation of blood vessels ${ }^{(9)}$.

\section{AIM OF THE WORK}

The main aim of this study was to investigate the serum leptin level and its correlations with serum ferritin level in children with $\beta$ thalassemia major.

\section{PATIENTS AND METHODS}

This study was performed in the Pediatric Hematology Unit of Al-Azhar University Hospitals (Sayed Galal and AlHussien Hospitals).

A case-control study was used. Children were classified into two groups a group of 30 children suffering from $\beta$ thalassemia major attending for regular follow up at Hematology Clinic of El-Sayed Galal \& Al-Hussien University Hospitals (group1). Another group of 20 apparent healthy children with matched age and sex were included in the study as a normal control group (group 2). Sexual maturity was assessed in both groups as age group $13-17$ years using tunner stage.

Inclusion criteria of patient with Bthalassemia major

- Diagnosis depended on hemoglobin electrophoresis.

- $\quad$ Receiving regular packed red blood cells transfusion.

\section{Exclusion criteria:}

- Family history of diabetes mellitus.

- Children on corticosteroids therapy.

- $\quad$ Obese children.

- Children with renal affection.

\section{Data collection methods:}

A pre designed structured interview questionnaire (appendix) was used to collect the following data from the mothers:

A. History:

Personal data: Child personal data: Like name, age by years, gender and residence.

History of present illness: Which include: symptoms of the disease and its complications and frequency of blood transfusion.

\section{B.Anthropometric assessment:}

Weight in kilograms and height in centimeters were measured for all children included in the study according to criteria of Jellife ${ }^{(10)}$.

\section{i. Weight:}

Weight was measured in kilograms using a bath scale. The scale was calibrated, checked against a known weight before use and frequently rechecked before weighting each child. Before use, the scale was placed on hard flat surface and balanced by setting at zero and it was noted if the balance registers exactly in the middle of the mark. The children were weighted without shoes and minimum clothing worn. Weight was recorded to the nearest 0.1 $\mathrm{kg}$.

\section{ii. Height:-}

Height measured in centimeters using non-stretchable tape fixed in the balance. After removing the shoes and anything on the head, the children stood up in an erect position on the balance base with feet hold together neither slumped nor stretched with the head in Frankfort position. Height was recorded to the nearest $0.1 \mathrm{~cm}$.

\section{iii. Body mass index:-}

$$
\begin{aligned}
& \text { Calculation: } \mathrm{BMI}=\text { weight in } \mathrm{kg} / \\
& \text { (height in meters) } \\
& \text { Interpretation: using BMI percentile }
\end{aligned}
$$
which allows comparison with children of the same sex and age. A BMI that is less than the 5 th percentile is considered underweight and above the 95th percentile is considered obese. 
BMI between the 85 th and 95 th percentile were considered overweight ${ }^{(11)}$.

\section{Clinical examination: which include}
i. Manifestations of the disease
ii. Any evidence of complications.
iii. Tunner staging of age group $13-17$.

\section{D. laboratory investigation:}

i. Complete blood picture and ferritin level.

ii. Serum leptin using a sensitive ELISA sandwich kit. (Vincent,et al. 2003) ${ }^{(12)}$.

\section{Calculation of Results}

1. The average absorbance values for each set of standards, control and patient samples were calculated.

2. A standard curve was constructed by plotting the mean absorbance obtained from each standard against its concentration with absorbance value on the vertical (Y) axis and concentration on the horizontal (X) axis.

3. The mean absorbance value for each sample determined the corresponding concentration from the standard curve.

4. The results in the IFU had been calculated automatically using a 4 PL (4 Parameter Logistics) curve fit.

5. The concentration of the samples was red directly from the standard curve. Samples with concentrations higher than that of the highest standard were further diluted. For the calculation of the concentrations this dilution factor was taken into account.

\section{Data processing and analysis:}

After data collection, raw data were coded and coding instruction manual was prepared. Data were fed to the computer using Statistical Package for Social Sciences (SPSS version 20).

\section{Data processing:}

Series of comprehensive checks were made to ensure correct data collection, making corrections whenever possible and ensure that all questions had valid codes.

\section{Data analysis:}

Descriptive statistics (frequency tables) were generated related to sample characteristics and other variables of interest. The arithmetic mean, standard deviation and percentage were used as summary statistics. A $\mathrm{P}$-value of 0.05 was used for statistical significance. Cross tabulation using Chi square and Fissure exact test, and independent $\mathrm{t}$ test were applied to get statistical significance of relations between variables.

\section{Ethical considerations:}

1. Written consent for the study was obtained from the parents or caregivers and all risks and benefits of the study were explained to them.

2. The patients had the right to withdraw from the study at any time.

3. The data of the patients and the results of the study are confidential and the patients had the right to keep them.

4. Approval from the Ethical Committees of Faculty of Medicine, Al-Azhar University was obtained before the study.

5. The authors received no financial support for the study or the publication.

\section{Results}


The results of the present study were as following:

Table (1): Comparison between patient and control groups regarding demographic data

\begin{tabular}{|c|c|c|c|c|}
\hline & $\begin{array}{l}\text { Patient } \\
(\mathrm{n}=30)\end{array}$ & $\begin{array}{c}\text { Control } \\
(\mathrm{n}=20)\end{array}$ & $P$ value & Sig. \\
\hline $\begin{array}{l}\text { Age (Year) } \\
\text { Range } \\
\text { Mean } \pm \text { SD }\end{array}$ & $\begin{array}{c}8-17 \\
13.78 \pm 2.36\end{array}$ & $\begin{array}{c}8-16.5 \\
13.03 \pm 2.9\end{array}$ & 0.835 & NS \\
\hline $\begin{array}{l}\text { Sex } \\
\text { Male/female }\end{array}$ & $14(46.7 \%) / 16(53.3 \%)$ & $7(35 \%) / 13(65 \%)$ & 0.333 & NS \\
\hline $\begin{array}{l}\text { Weight }(\mathrm{kg}) \\
\text { Range } \\
\text { Mean } \pm \text { SD }\end{array}$ & $\begin{array}{c}21.5-46.2 \\
37.8 \pm 10.7\end{array}$ & $\begin{array}{c}34-53.5 \\
42.1 \pm 4.1\end{array}$ & 0.032 & $\mathbf{S}$ \\
\hline $\begin{array}{l}\text { Height }(\mathrm{cm}) \\
\text { Range } \\
\text { Mean } \pm \text { SD }\end{array}$ & $\begin{array}{c}119-151 \\
138.1 \pm 6.2\end{array}$ & $\begin{array}{c}126.5-161 \\
147.26 \pm 6.41\end{array}$ & 0.021 & $\mathbf{S}$ \\
\hline $\begin{array}{l}\text { BMI } \\
\text { Range } \\
\text { Mean } \pm \text { SD }\end{array}$ & $\begin{array}{l}14.2-21.30 \\
17.1 \pm 1.1\end{array}$ & $\begin{array}{l}16.3-23.6 \\
19.2 \pm 3.8\end{array}$ & 0.002 & $\mathbf{S}$ \\
\hline
\end{tabular}

S: P-Value <0.05(Significant) $\quad$ HS: P-Value $<0.001$ (Highly Significant) $\quad$ NS: P-Value $>0.05$ (Non Significant).

This table revealed that there was a non-significant difference between case and control groups regarding age and sex ( $p>0.05)$. The weight, height and Body mass index (BMI) was significally lower between thalassemic patients compared to control group . (P value $<0.05)$.

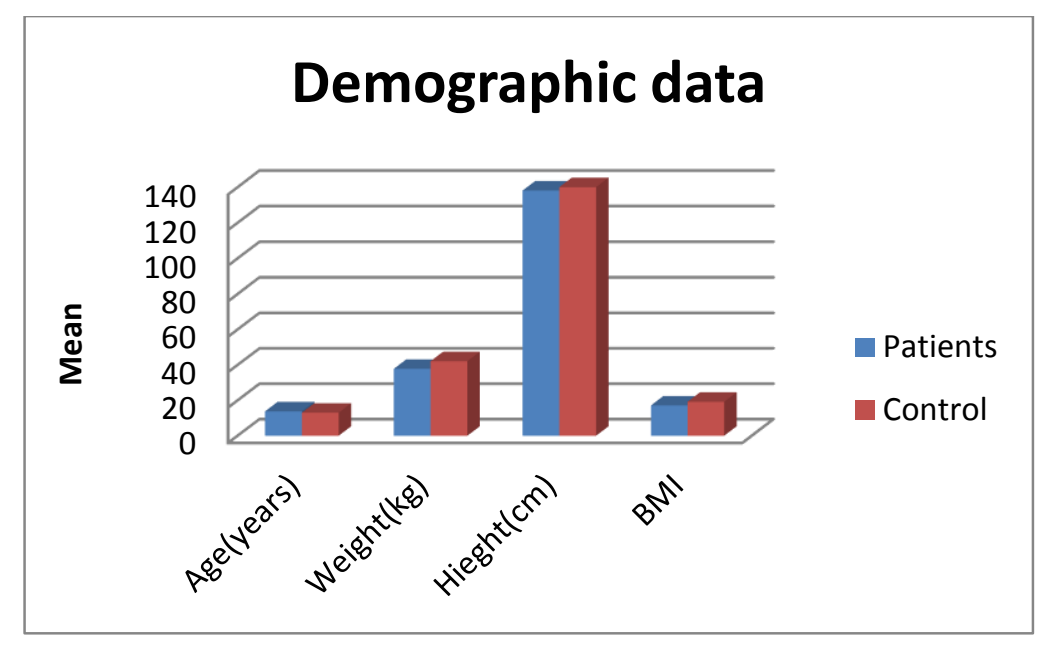

Figure (1 a): Comparison between patient and control group regarding demographic data (age, weight,height and BMI). 


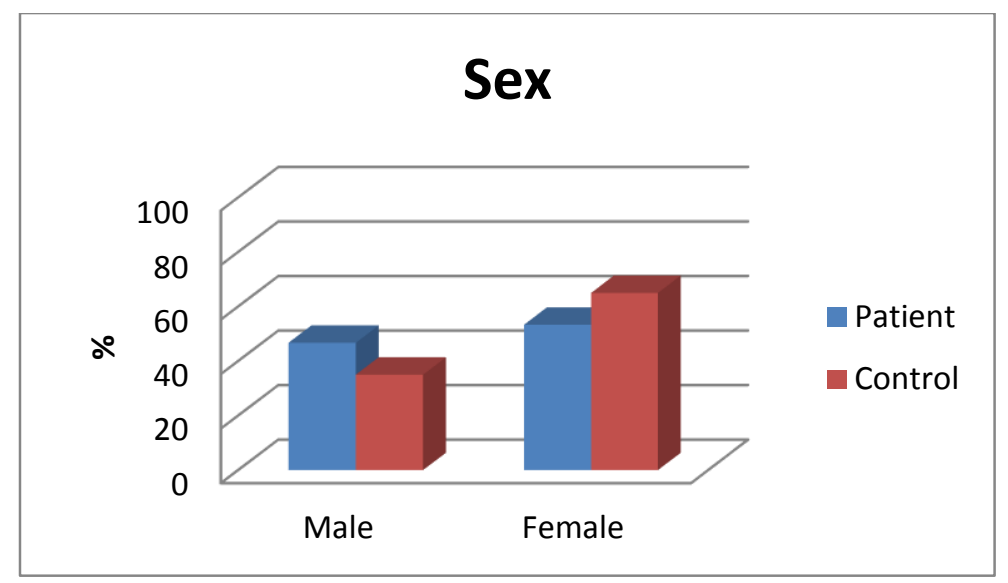

Figure (1 b): Comparison between patient and control group regarding sex difference.

Table (2): Comparison between patient and control groups regarding Tunner staging in patients (1317 years)

\begin{tabular}{|l|c|c|}
\hline Tunner staging & $\begin{array}{c}\text { Patient } \\
(\mathrm{n}=12)\end{array}$ & $\begin{array}{c}\text { Control } \\
(\mathrm{n}=8)\end{array}$ \\
\hline $\begin{array}{l}\text { Stage I } \\
\text { Number (\%) }\end{array}$ & $11(91.7)$ & $0(0)$ \\
\hline $\begin{array}{l}\text { Stage II } \\
\text { Number (\%) }\end{array}$ & $1(8.3)$ & $1(12.5)$ \\
\hline $\begin{array}{l}\text { Stage III } \\
\text { Number (\%) }\end{array}$ & $0(0)$ & $5(62.5)$ \\
\hline $\begin{array}{l}\text { Stage IV } \\
\text { Number (\%) }\end{array}$ & $0(0)$ & $1(12.5)$ \\
\hline $\begin{array}{l}\text { Stage V } \\
\text { Number (\%) }\end{array}$ & $0(0)$ & $1(12.5)$ \\
\hline
\end{tabular}

This table showed that there was $91.7 \%$ of studied thalassemic patients had not attained puberty.

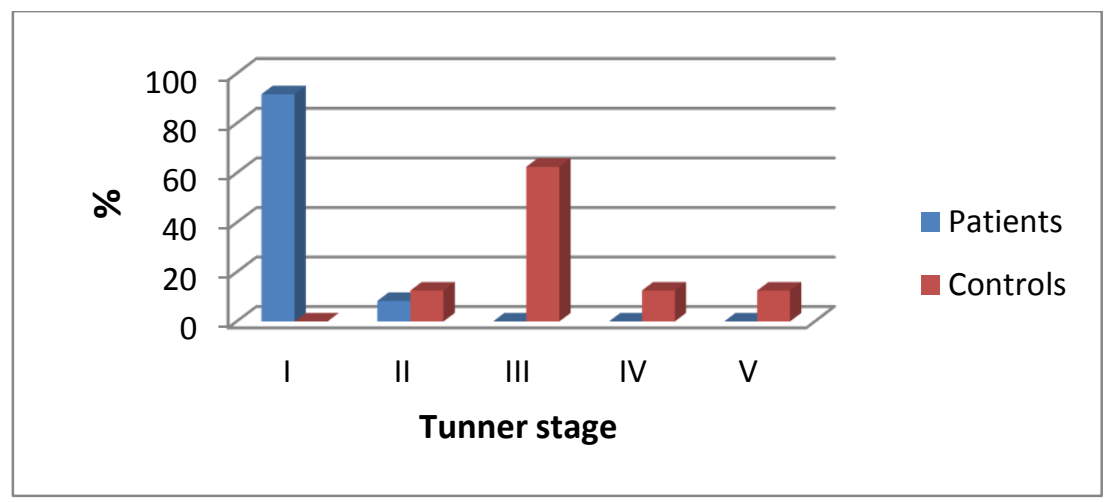

Figure (2): Comparison between patient and control group regarding Tunner staging in group age (13-17 years). 
Table (3): Comparison between patient and control group regarding laboratory data

\begin{tabular}{|c|c|c|c|c|}
\hline & Patient $(n=30)$ & Control $(n=20)$ & $P$ value & Sig. \\
\hline $\begin{array}{l}\text { Hb }(\mathrm{gm} / \mathrm{dl}) \\
\text { Range } \\
\text { Mean } \pm \mathrm{SD}\end{array}$ & $\begin{array}{l}4.2-10.1 \\
6.5 \pm 1.4 \\
\end{array}$ & $\begin{array}{l}10.5-12.5 \\
11.6 \pm 0.6\end{array}$ & $<0.001$ & HS \\
\hline $\begin{array}{l}\text { WBCs (number } / \mathrm{mm}) 3 \\
\text { Range } \\
\text { Mean } \pm \mathrm{SD}\end{array}$ & $\begin{array}{l}6.6-16.1 \\
9.6 \pm 2.3 \\
\end{array}$ & $\begin{array}{c}6.1-9.8 \\
7.9 \pm 1.2 \\
\end{array}$ & 0.012 & $\mathbf{S}$ \\
\hline $\begin{array}{l}\text { RBCs } /(\mathrm{mm}) 3 \\
\text { Range } \\
\text { Mean } \pm \text { SD }\end{array}$ & $\begin{array}{c}2.9-3.28 \\
2.88 .3 \pm 0.58\end{array}$ & $\begin{array}{c}3.7-4.2 \\
3.45 \pm 0.91\end{array}$ & 0.067 & NS \\
\hline $\begin{array}{l}\text { Platlets (number } / \mathrm{mm}) 3 \\
\text { Range } \\
\text { Mean } \pm \text { SD }\end{array}$ & $\begin{array}{c}220-260 \\
383.0 \pm 9.8 \\
\end{array}$ & $\begin{array}{c}180-220 \\
294.7 \pm 7.9 \\
\end{array}$ & 0.003 & $\mathbf{S}$ \\
\hline $\begin{array}{l}\text { Serum Leptin }(\mathrm{ng} / \mathrm{ml}) \\
\text { Range } \\
\text { Mean } \pm \text { SD }\end{array}$ & $\begin{array}{c}0.2-0.3 \\
1.1 \pm 0.1\end{array}$ & $\begin{array}{c}0.8-0.2 \\
2.62 \pm 0.6\end{array}$ & $<0.001$ & HS \\
\hline $\begin{array}{l}\text { Retics }(\%) \\
\text { Range } \\
\text { Mean } \pm \text { SD }\end{array}$ & $\begin{array}{c}2.5-4.2 \\
3.4 \pm 0.5\end{array}$ & $\begin{array}{c}0.3-0.8 \\
1.01 \pm 0.2\end{array}$ & 0.003 & $\mathbf{S}$ \\
\hline $\begin{array}{l}\text { Serum Ferritin }(\mathrm{ng} / \mathrm{ml}) \\
\text { Range } \\
\text { Mean } \pm \mathrm{SD}\end{array}$ & $\begin{array}{c}1700-504 \\
3256.67 \pm 507.34\end{array}$ & $\begin{array}{c}30-100 \\
68.13 \pm 11.14\end{array}$ & $<0.001$ & HS \\
\hline
\end{tabular}

This table revealed that there was severe anemia and $\mathbf{H b} \%$ was highly significant lower in thalassemic children compared to controls. Adversely, Platelets, WBCs and reticulocytes were significantly higher in patients compared to controls ( $p$ value $<0.001$ ). Serum ferritin was significantly higher in patients than control ( $p$ value $<0.001$ ). Serum leptin level was highly significant lower in thalassemia group of patients than in control group.

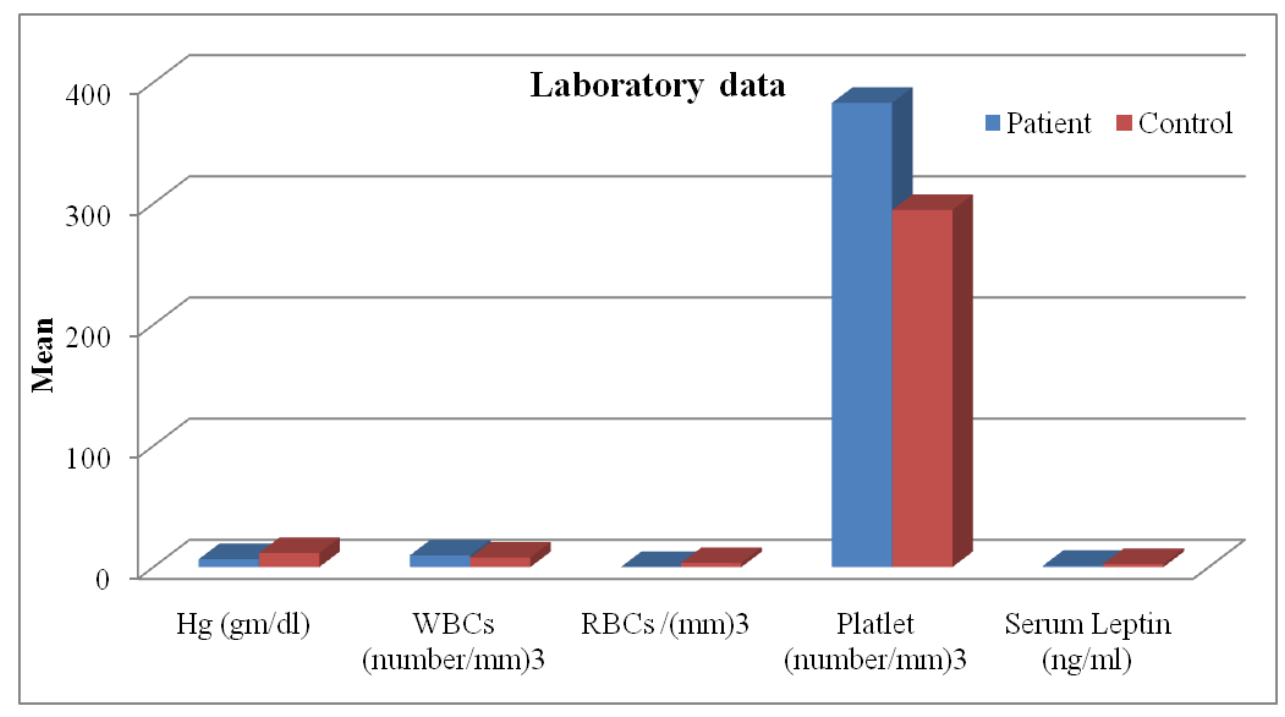

Figure (5 a) 
Ahmed Asfour et al.

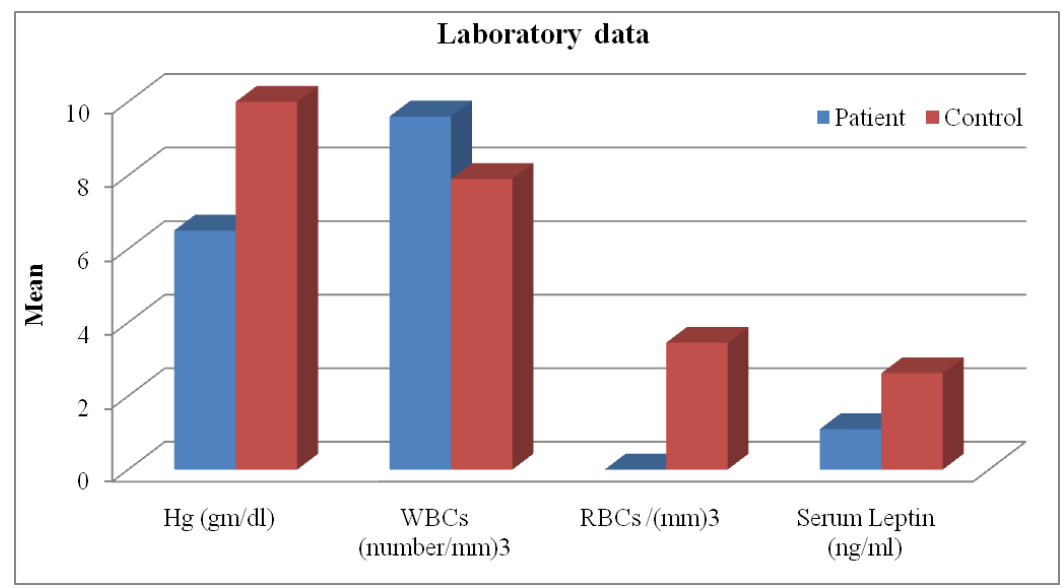

Figure (5 b)

Figure (5 a,b): Comparison between patient and control group regarding laboratory data .

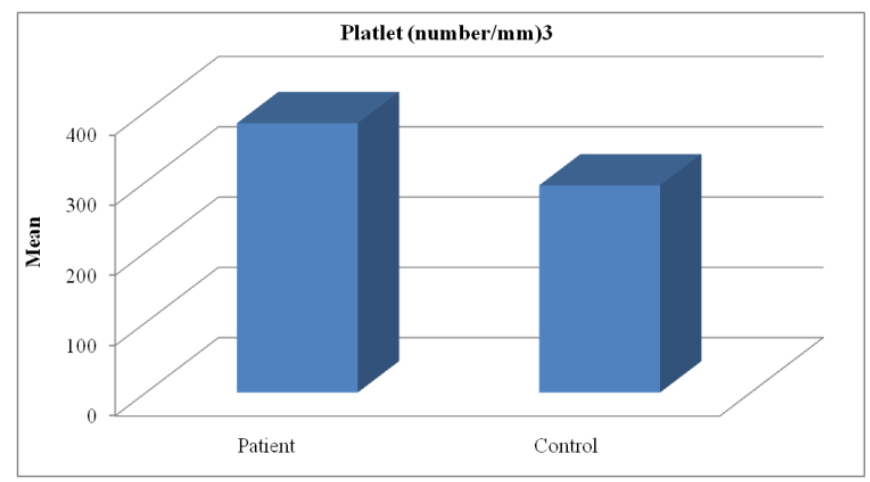

Figure (5 c): Comparison between patient and control group regarding platlets count .

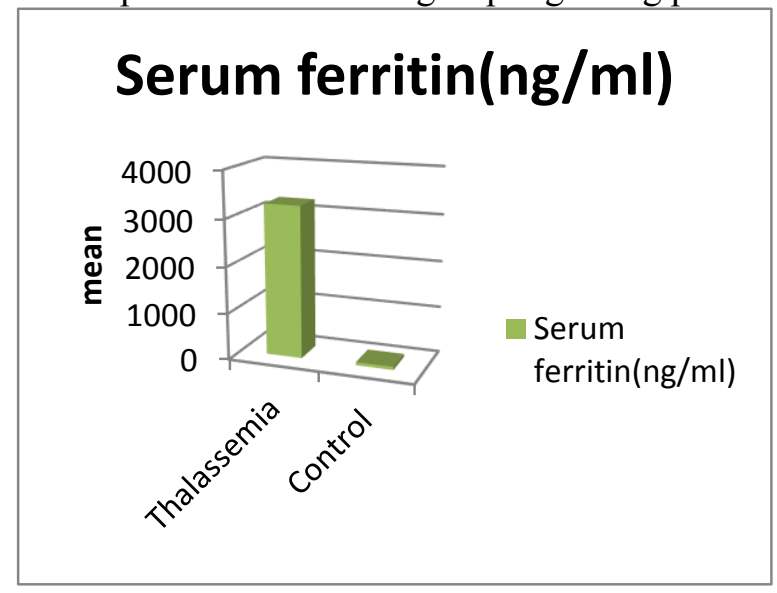

Figure (5d): Comparison between patient and control group as regarding serum ferritin level. 
Table (4): Correlation between serum leptin and the different clinical and laboratory parameters in patient group

\begin{tabular}{|l|c|c|c|}
\hline \multirow{2}{*}{\multicolumn{1}{|c|}{ Thalassemic patients parameters }} & \multicolumn{2}{c|}{ Serum leptin } & \multirow{2}{*}{ Sig. } \\
\cline { 2 - 3 } & $\begin{array}{c}\text { Test of } \\
\text { significance }\end{array}$ & P value & \\
\hline Age (Year) & $\mathrm{r}=0.3$ & 0.059 & $\mathrm{NS}$ \\
\hline Duration of illness (Year) & $\mathrm{r}=0.3$ & 0.081 & $\mathrm{NS}$ \\
\hline Frequency of blood transfusion & $\mathrm{r}=0.1$ & 0.772 & $\mathrm{NS}$ \\
\hline Weight (kg) & $\mathrm{r}=0.3$ & 0.067 & $\mathrm{NS}$ \\
\hline Height (cm) & $\mathrm{r}=0.2$ & 0.224 & $\mathrm{NS}$ \\
\hline BMI & $\mathrm{r}=0.5$ & 0.045 & S \\
\hline HB (gm/dl) & $\mathrm{r}=0.3$ & 0.133 & $\mathrm{NS}$ \\
\hline WBCs (number/mm)3 & $\mathrm{r}=-0.2$ & 0.256 & $\mathrm{NS}$ \\
\hline RBCs (number/mm)3 & $\mathrm{r}=0.4$ & 0.019 & S \\
\hline Platlet (number/mm)3 & $\mathrm{r}=0.0$ & 0.901 & $\mathrm{NS}$ \\
\hline Retics (\%) & $\mathrm{r}=-0.2$ & 0.321 & $\mathrm{NS}$ \\
\hline Serum Ferritin (mcg)/l & $\mathrm{r}=0.6$ & 0.041 & S \\
\hline
\end{tabular}

$\mathrm{r}=$ Spearman correlation coefficient

This table revealed that there was significant positive correlation of leptin level in thalassemic patients with body mass index ( $\mathrm{p}$ value $<0.05$ ). Also, there was significant negative correlation of leptin level in thalassemic patients with serum ferritin ( $\mathrm{p}$ value $<0.05$ ). No significant correlation of leptin level in thalassemic patients with either $\mathrm{Hb} \%$, WBCs count, platelet count and reticulocytic count. No significant correlation of serum leptin level in thalassemic patients with clinical characterstics like age, weight or height ( $\mathrm{p}$ value $>0.05$ ).

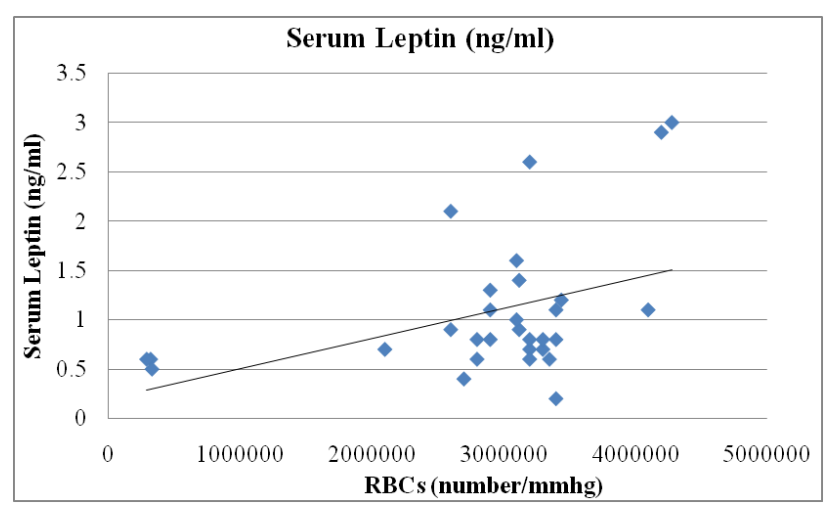

Figure (6 a): Correlation coefficient between leptin and RBCs (N / mmhg). 


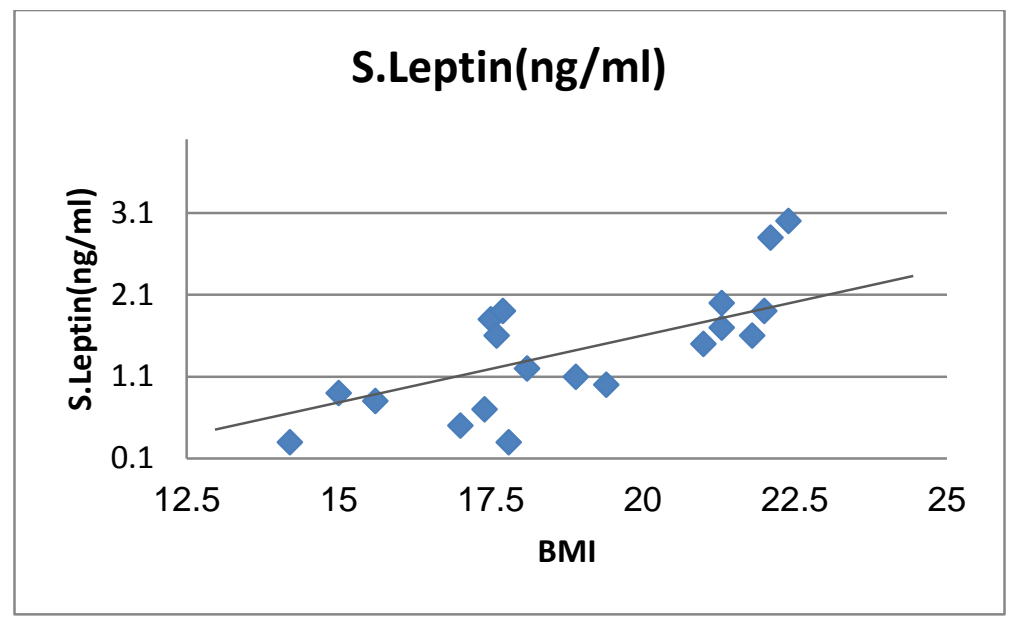

Figure (6 b): Correlation coefficient between leptin and BMI.

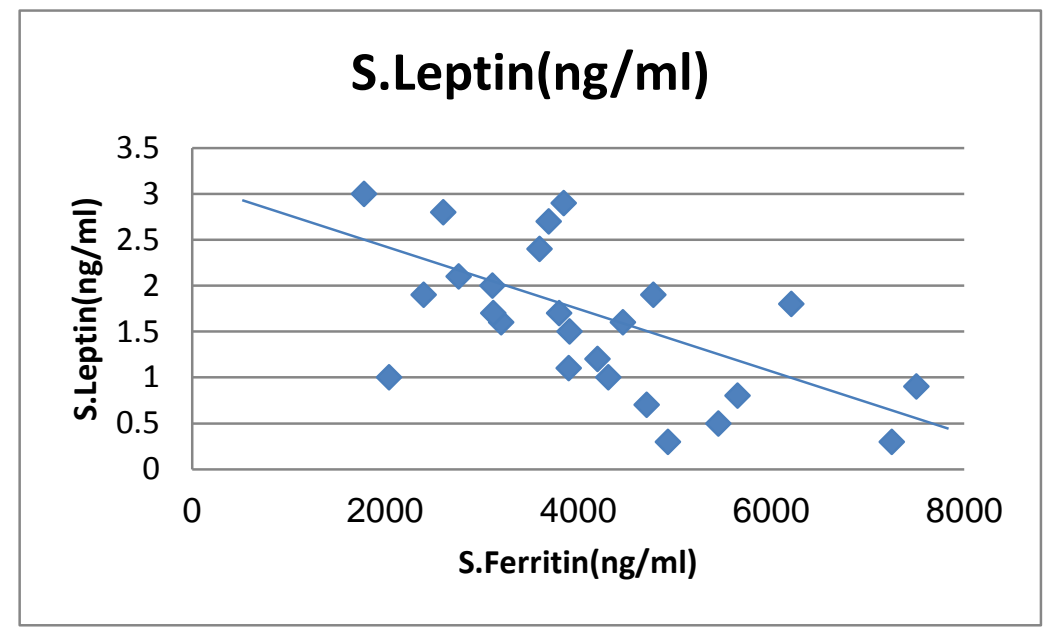

Figure (6 c): Correlation coefficient between leptin and serum ferritin level .

Table (5): Comparison between patient on Iron chelators and patients not receiving iron chelators:

\begin{tabular}{|c|c|c|c|c|}
\hline & $\begin{array}{c}\text { No chelators } \\
(n=5)\end{array}$ & Iron chelators $(n=25)$ & P value & Sig. \\
\hline $\begin{array}{l}\mathrm{Hg}(\mathrm{gm} / \mathrm{dl}) \\
\text { Mean } \pm \text { SD }\end{array}$ & $6.9 \pm 1.4$ & $6.5 \pm 1.4$ & 0.578 & NS \\
\hline $\begin{array}{l}\text { WBCs (number/mm)3 } \\
\text { Mean } \pm \text { SD }\end{array}$ & $9.6 \pm 2.0$ & $9.6 \pm 2.4$ & 0.987 & NS \\
\hline $\begin{array}{l}\text { RBCs (number/mm)3 } \\
\text { Mean } \pm \text { SD }\end{array}$ & $2750000.0 \pm 42289.8$ & $2916000.0 \pm 4825.0$ & 0.737 & NS \\
\hline $\begin{array}{l}\text { Platlet }(\text { number } / \mathrm{mm}) 3 \\
\text { Mean } \pm \text { SD }\end{array}$ & $338.0 \pm 8.2$ & $392.0 \pm 9.9$ & 0.252 & NS \\
\hline $\begin{array}{l}\text { Serum Leptin (ng/ml) } \\
\text { Mean } \pm \text { SD }\end{array}$ & $1.1 \pm 0.01$ & $1.4 \pm 0.2$ & 0.461 & NS \\
\hline $\begin{array}{l}\text { Retics }(\%) \\
\text { Mean } \pm \text { SD }\end{array}$ & $3.0 \pm 0.4$ & $3.4 \pm 0.4$ & 0.034 & $\mathbf{S}$ \\
\hline $\begin{array}{l}\text { Serum Ferritin }(\mathrm{mcg}) \\
\text { Mean } \pm \text { SD }\end{array}$ & $3374.0 \pm 76.7$ & $1653.6 \pm 94.9$ & 0.011 & $\mathbf{S}$ \\
\hline $\begin{array}{l}\text { Hb A }(\%) \\
\text { Mean } \pm \text { SD }\end{array}$ & $54.1 \pm 7.2$ & $55.0 \pm 7.8$ & 0.925 & NS \\
\hline $\begin{array}{l}\text { Hb A2 (\%) } \\
\text { Mean } \pm \text { SD }\end{array}$ & $2.9 \pm 0.5$ & $2.8 \pm 0.7$ & 0.927 & NS \\
\hline $\begin{array}{l}\text { Hb F (\%) } \\
\text { Mean } \pm \text { SD }\end{array}$ & $43.0 \pm 6.9$ & $42.1 \pm 8.4$ & 0.932 & NS \\
\hline
\end{tabular}


This table revealed that there was no significant difference between patients on iron chelators and patients not receiving iron chelators regarding $\mathrm{HB}, \mathrm{WBCs}, \mathrm{RBCs}$, platlets count, S.leptin, $\mathrm{Hb} \mathrm{A}$, $\mathrm{Hb} \mathrm{A} 2$ or $\mathrm{Hb} \mathrm{F}$.

Serum Ferritin was significantly higher in patient not receiving chelators than those receiving chelators $(\mathrm{P}=0.034$ and 0.011$)$ respectively.

Retics were significantly higher in those receiving iron chelators (P value 0.034 ).

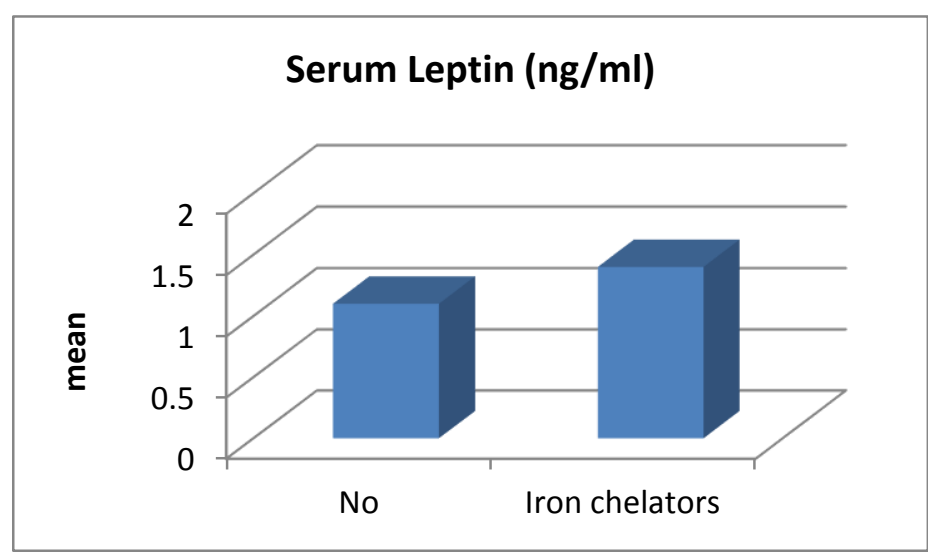

Figure (9 d): Comparison between patient on iron chelators and patient not receiving iron chelators as regarding serum Leptin level.

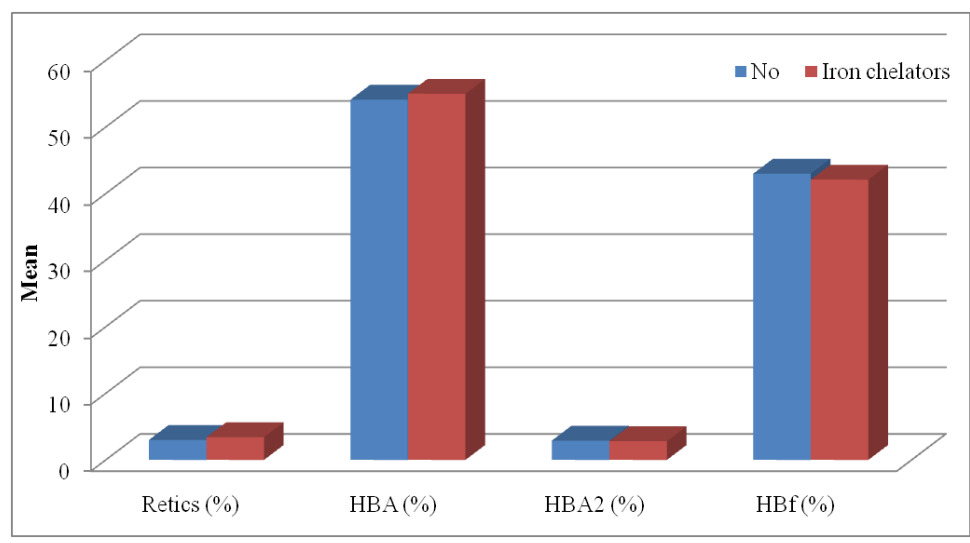

Figure (9 e): Comparison between patient on Iron chelators and patients not receiving iron chelators as regarding laboratory data (Retics, $\mathrm{Hb} \mathrm{A}, \mathrm{Hb} \mathrm{A} 2$ and $\mathrm{Hb} \mathrm{F}$ ) in patients group .

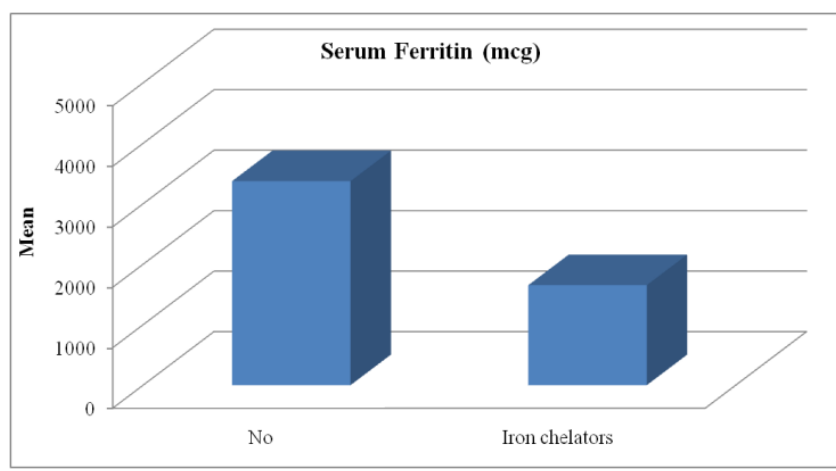

Figure (9 f):Comparison between patient on Iron chelators and patients not receiving iron chelators as regarding serum Ferritin. 


\section{Discussion}

Beta-thalassemia is a group of frequent genetic disorders resulting in the synthesis of little or no $\beta$-globin chains. Novel approaches are being developed to correct the resulting $\alpha / \beta$-globin chain imbalance, in an effort to move beyond the palliative management of this disease and the complications of its treatment (e.g. life-long red blood cell transfusion, iron chelation, spleenectomy)

Beta thalassaemia major patients in our set up were facing all the problems associated with iron overload, improper chelation and transfusion associated infections. In the present study majority of the patients showed very high serum ferritin levels. The mean serum ferritin among cases was $(3256.67 \pm 1507.34)$. In studies conducted by Shahramian et al. ${ }^{(13)}$ and Ikram et al. ${ }^{(14)}$, they reported that serum ferritin levels in patients were higher than in normal children, which is consistent with our results.

The present study included 30 multitransfused $\beta$-thalassemia major patients. They were 14 males and 16 females with mean age of $13.78 \pm 2.36$ years old. Another group of 20 apparent healthy children with matched age and sex was included in the study as a control group. They were 7 males and 13 females with mean age of $13.03 \pm 2.9$ years old. We focused on multitransfused $\beta$-thalassemia major children because of their high frequency of blood transfusion that were suspected to be associated with high serum ferritin level. Moreover, high serum ferritin level was an inclusion criterion for our study because this high level of serum ferritin is associated with higher incidence of hemosiderosis, which is a cause of multiple complications including endocrinal complications, one of which is affection of serum leptin level ${ }^{(15)}$.

The current study included patients older than 8 years, as they were suspected to have high serum ferritin level with its possible complications, to record their anthropometric measurements (weight and height) and BMI, and monitor any possible association between these measurements and serum leptin level. In addition, sexual maturity was assessed in both groups in age group 13 - 17 years using Tunner staging. Besides, there was a non-significant difference between case and control groups regarding age and sex $(p>0.05)$. This denoted uniformity of the study groups and any further results could not be attributed to differences in age or sex between the two groups. In the present study, the anthropometric measurements domenestrated significant difference in both groups as regard weight, height and BMI as they were lower in thalassemic patients compared to controls. The weight was significally lower among thalassemic patients compared to control group. Also, height was significally lower among thalassemic patients compared to control group. Moreover body mass index (BMI) of studied groups was significally lower among thalassemic group than control. In coincidence with our study, Fahim et al. ${ }^{(16)}$ studied growth parameters in children with thalassemia major in Upper Egypt. They found that $49 \%$ of their patients had short stature, $47 \%$ were underweight and BMI of $43(43 \%)$ patients were low. Also, Salih and Al Mosawy (17) found that the weight and BMI of thalassemic patients were significantly lower than those in control group. In contrary to our study, Mohey El-Deen et al ${ }^{\left({ }^{(18)}\right.}$ found that children with $\beta$ thalassemia major revealed no significant difference in weight and BMI between the studied thalassemic patients compared to control group, and this was mostly explained by that these patients were under good and strict hematological control and nutritional care.

Impaired puberty in beta-thalassemia major patients included delayed puberty, arrested puberty and hypogonadism. Delayed puberty was defined as the absence of breast enlargement in girls and testicular enlargement in boys (tunner stage 2) by the age of 13 and 14 years respectively. Arrested puberty is defined as the absence of pubertal progression for more than one year after puberty onset, where testicular volume in boys is less than 6 to $8 \mathrm{ml}$ and unchanged breast size in girls. Puberty onset delay more than 2 SD beyond the mean for sex was considered as hypogonadism ${ }^{(19)}$. In our study, $91.7 \%$ did not attain puberty, which included $54.5 \%$ of the boys and $45.5 \%$ of the girls (with $100 \%$ of girls having primary amenorrhea. In agreement with us, a study in Iran reported that 35 thalassemic patients (16 females and 19 males), aged between 13 and 24 years showed that $60 \%$ of the patients did not attain 
puberty. This group included $36.8 \%$ of the boys and $87.5 \%$ of the girls with $87.5 \%$ of girls having primary amenorrhea ${ }^{(20)}$. De Sanctis and coworkers ${ }^{(21)}$ in a study group of 238 patients aged 2-17 years with betathalassemia major that were regularly followed in 13 pediatric and hematological Italian centers. They found delayed puberty in $18.4 \%$ of boys and $17.7 \%$ of girls. In a followup study by Low L.C. of 41 patients older than 14 years old, spontaneous puberty only occurred in $32 \%$ of the patients. ${ }^{(22)}$.

In our present study CBC parameters showed severe anemia in thalassemic patients, $\mathrm{Hb} \%$ was highly significant lower in thalassemic children compared to controls. Adversely, platelets were significantly higher in patients compared to controls. There was a nonsignificant difference between the two groups regarding WBCs count. In coincidence with our study, Bayejid et al. ${ }^{(23)}$ found that $\mathrm{Hb} \%$ level was significantly lower among the thalassemic patients compared to the controls. In addition, Hussain et al. (24) in astudy of pattern of thalassmias found that all the patients of beta thalssemia major had severe anemia.

In the current study, serum ferritin level showed extremely significant high serum levels in thalassemia group compared to control group. In coincidence with our study, Eghbali et al. ${ }^{(25)}$ who studied sixty-six patients with major beta thalassemia in Amir Kabir hospital, Arak, Iran. They found that mean serum ferritin level was1912 $\pm 1748 \mathrm{ng} / \mathrm{ml}$ and its range was from 303 to $8333 \mathrm{ng} / \mathrm{ml}$. Mahmoud and Aziz (26) found that serum level of ferritin in transfusion dependent $\beta$-Thalassemic patients compared to the control, was significantly elevated in all patients.

Leptin in the thalassemic patients of our study was significantly lower than that in the healthy subjects. This was in agreement with the Karachaliou et al. ${ }^{(27)}$ findings in $33 \beta$ thalassemic patients with the mean age of 19.3 years where mean $S$. leptin was $1.55 \pm 1.35$ vs $3.02 \pm 1.96$ in healthy control ( $\mathrm{P}$ value 0.032 ). Another study on $219 \beta$-thalassemic patients reported that adipocytes were unable to maintain adequate leptin production ${ }^{(2)}$. This finding also agreed with other previous studies of Dayer et al. (28). They found that such decrease in leptin level in patients with $\beta$ thalassemia major is due to toxic effects of iron on cell membranes and proteins where free iron causes peroxidative damage in lipid membrane and proteins with the generation of free $\mathrm{O} 2$ radicals. Thus, in iron overload following the destructions of adipocyte, leptin level is decreased (28). Moreover, other studies investigated serum leptin level and reported that it was lower in major thalassemia patients compared to healthy controls ${ }^{(29)}$.

In the present study, linear regression coefficients were used to determine relationships of leptin with different parameters of patients, which showed that there was significant correlation with BMI, RBCs levels and serum ferritin levels ( $p$ value < 0.05 ). In our current study, there was a significant positive correlation between BMI and serum leptin level in thalassemia group of patients $(\mathrm{rs}=0.5, \mathrm{p}=$ 0.045). This could be attributed to that the increased fat mass led to an increase in leptin production ${ }^{(30)}$. In coincidence with our study, Shahramian et al. ${ }^{(31)}$ found a significant correlation between BMI and leptin $(r=0.374$, $\mathrm{P}=0.002$ ).

Contrary to us, Choobineh et al ${ }^{(9)}$ found that leptin level and BMI had no significant correlation in beta thalassemia major patients $(\mathrm{P}$-value $=0.67)$. The difference between our study and that study could be attributed to a toxicity of iron overload on bone marrow and suggests a less active role of body fat mass in the regulation of circulating leptin in these patients. Animal studies have shown that iron overload and its deposition in subcutaneous layers significantly inhibits adipocyte function (32).

Our current study revealed significant negative correlation between serum leptin and ferritin ( $\mathrm{rs}=0.6, \mathrm{P}=0.04$ ) level in major $\beta$ thalassemia. This might be resorted to that fat cells in thalassemia patients are unable to produce leptin, partly due to the toxic effects of increased iron and ferritin levels that became higher with advancement in age, and the result of this increase in ferritin is the reduction in level of leptin. In agreement with our study, Shahramian et al. (13) found an inverse statistical correlation between serum levels of leptin and ferritin among 90 beta thalassemia major children $(\mathrm{P}<0.05)$.

In our present study, S. Leptin level was low in patient group in both males and females and was much lower in males than in females but there was no significant correlation between serum leptin and sex genders. Dedousiss et al. (4) showed an inverse 
relationship between plasma levels of leptin and receptor level of transferring solvent in patients with thalassemia where leptin was higher in female than in male. This is due to the less mRNA expression of leptin in males compared to females. The second reason is that sex hormones have an important role in the regulation of leptin. Shahramian et al. ${ }^{(13)}$ also showed a significant statistical difference between male and female in case group.

Our study showed that there were no significant difference between patients receiving iron chelators and those not receiving chelators regarding laboratory data apart from difference in ferritin level which was significantly higher in those not receiving chelators and retics ratio that was significantly higher between those receiving chelators.

\section{Conclusion}

Importantly, every $\beta$-thalassemia major $(\beta T M)$ patient requires proper management and strict follow-up. Early diagnosis and treatment with chelating agents are essential to prevent complications and for a better quality of life. A deeper knowledge of the pathogenesis and manifestation of $\beta$ TM as well as innovative new treatments are essential to prevent endocrine complications and iron overload and this will result in better life for $\beta$ TM patients.

\section{References}

1. Noori N M, Keshavarz K, Shahriar M (2012): Cardiac and pulmonary dysfunction in asymptomatic betathalassemia major. Asian Cardiovasc Thorac Ann., 20: 555-9.

2. Choobineh H, Dehghani J, Einollahi $\mathrm{N}$ et al. (2007): Comparison of serum in major $\beta$-thalassemia patients and normal subjects. Iranian J Pediatr., 17 (1): 73-8.

3. Gainsford T, Alexander W S (2000): A role for leptin in hemopoieses? MolBiotechnol., 11 (2): 149-58.

4. Dedoussis V, Kyrtsonis C, Andrikopoulos E et al. (2002): Inverse correlation of plasma leptin and soluble transferring receptor levels in $\beta$-thalassemia patients. Ann Hematol., 81 (9): 543-7.

5. Bennett B D, Solar G P, Yuan J Q et al. (1996): A role for leptin and its cognate receptor in hematopoiesis. Curr Biol., 6 (9):1170-80.
6. Cao A, Galanello R, Rosatelli M (2010): Prenatal diagnosis and screening of the haemoglobinopathies. Baillieres Clin Haematol ., 11: 215-38.

7. Chaliasos N, Challa A, Hatzimichael E et al. (2010): Serum adipocytokine and vascular inflammation marker levels in beta- thalassemia major patients. Acta Haematol., 124(4):191-6.

8. Scott G, Yan G, Judith A et al. (2012): Adipocyte iron regulates adiponectin and insulin sensitivity. J Clin Invest ., 122(10): 3529-40.

9. Choobineh H, Dehghani S J, Alizadeh S H et al. (2009): Evaluation of Leptin Levels in Major Beta-Thalassemic Patients. IJHOSCR., 3(4):1-4

10. Jellife D (1989): The assessment of the nutritional status of the community. Geneva: World Health Organization. apps.who.int/iris/handle/10665/41780

11. Centers for Disease Control and Prevention (2011): CDC grand rounds: childhood obesity, 60:42-6.

12. Vincent T, Chow K, Phoon C (2003): Measurement of serum leptin concentrations in university undergraduates by competitive ELISA reveals correlations with body mass index and sex. Adv Physiol Educ., 27(2):70-7.

13. Shahramian I, Noori N, Ramezani A et al. (2013): Correlation between serum leptin level and thyroid hormones in children with major beta-thalassemia. Iran J Ped Hematol Oncol., 3(4):149-53.

14. Ikram N, Hassan K, Younas M et al. (2004): Ferritin Levels in Patients of Beta Thalassaemia Major. International Journal of Pathology, 2(2):71-4.

15. Lam W W, Au W Y, Chu W C et al. (2008): Tam S, Ha SY, Pennell DJ. Onestep measurement of iron deposition in the anterior pituitary, liver, and heart in thalassemia patients. J Magn Reson Imaging, 28(1):29-33.

16. Fahim F M, Saad K, Askar E A et al. (2013): Growth Parameters and Vitamin D status in Children with Thalassemia Major in Upper Egypt. Int J Hematol Oncol Stem Cell Res., 7(4):10- 4.

17. Salih K and Al Mosawy W (2013): Evaluation of some consequences of thalassemia major in splenectomized and non- splenectomized. Int $\mathrm{J}$ Pharm Pharm Sci., 5(4):385-8. 
18. Mohey El-Deen Z, Ismail A, Abdel Meguid M et al. (2014): Some endocrinal changes in children with $\beta$-thalassemia major. Egyptian Journal of Hematology, 39(3):103-8.

19. Fatemeh S, Abolfazl M, Shabnam J (2014): Endocrine and metabolic disorders in beta-thalassemia major patients. Caspian J Intern Med., 3(3): 466-472.

20. Rashid H , Amruta S ,Javed A (2011): Evaluation of Growth, Puberty and Endocrine Dysfunctions in Relation to Iron Overload in Multi Transfused Indian Thalassemia Patients Indian J Pediatr., 78(6):679-683.

21. De Sanctis V, Eleftheriou A, Malaventura C ( 2004): Thalassaemia International Federation Study Group on Growth and Endocrine Complications in Thalassaemia. Pediatr Endocrinol Rev., 2( 2): 249-55.

22. Ghosh S, Bandyopadhyay SK, Bandyopadhyay $R$ et al. (2008): A study on endocrine dysfunction in thalassaemia. $\mathbf{J}$ Indian Med Assoc., 106:655-9.

23. Bayejid Hosen, Md, Karmokar N, Karim F (2015): Association of AST, ALT, ALB and Total Protein with Beta- thalassemia in Bangladeshi Population. International Journal of Advanced Research, 3(1):991-5.

24. Hussain j, Arif S, Zamir S et al. (2013): Pattern of thalassmias and other hemoglobinopathies: a study in district Dera Ismail Khan, Pakistan. Gomal Journal of Medical Sciences, 11(2):174- 177.

25. Eghbali A, Taherahmadi H, Bagheri B et al. (2015): Association between serum ferritin level and diastolic cardiac function in patients with major $\beta$ thalassemia. Iran J Ped Hematol Oncol ., 5(2):83-8.

26. Mahmoud S, Aziz S (2013): Evaluation of Certain Inflammatory Markers in Transfusion Dependent $\beta$ Thalassemic Patients. Tikrit Journal of Pharmaceutical Sciences, 9(1): 80-90.

27. Karachaliou F, Vlachopapadopoulou E, Theochari $\mathrm{M}$ et al.(2006): Leptin levels in patients with thalassemia major. Minerva Pediatr ., 58: 373-8.

28. Dayer D, Salahcheh M, Mousavi J et al. (2012): Thyroid stimulating hormone and leptin levels and severe growth retardation among $\beta$ thalassemic patients. Pak J Med Sci ., 28 (3): 421-3.

29. Karami H, Kosarian M, Kowsarian S et al. (2011): The relationship between developing thalassemia major and dysfunction of pancreatic endocrine and exocrine. J Mazand Univ Med Sc., 21(83):2-7.

30. Suzuki K, Ito Y, Ochiai J et al. (2003): JACC Study Group Asian Pac J Cancer Prev., 4(3):259-66.

31. Shahramian I, Noori N M, Teimouri A et al. (2015): The Correlation between Serum Level of Leptin and Troponin in Children with Major Beta-Thalassemia. Iran J Ped Hematol Oncol.,5(1):11-7.

32. Lombardo T, Tamburino C, Bartolini G et al. (1995): Cardiac Iron Overload in Thalassemic Patients: An Endomyocardial Biopsy Study. Ann Hematol., 71:135-141. 